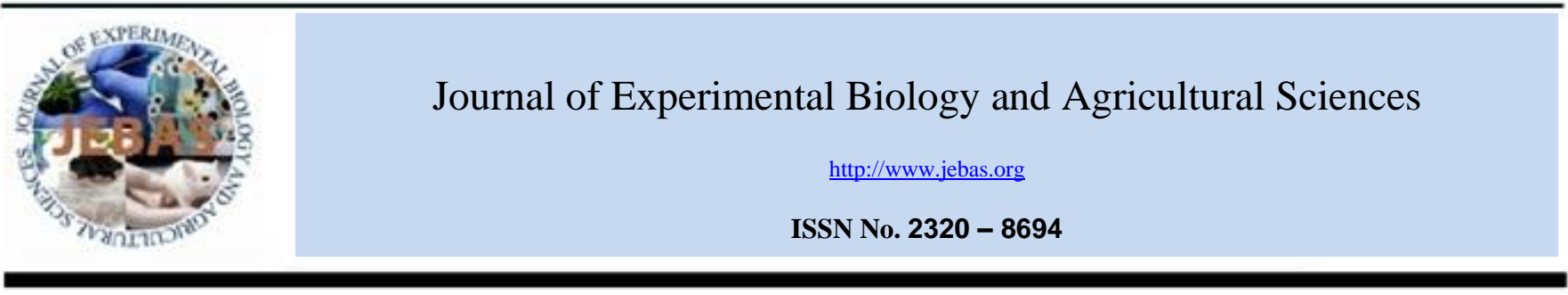

\title{
MULTIVARIATE ANALYSIS AND DROUGHT STRESS TOLERANCE INDICES IN CHICKPEA (Cicer arietinum L.) UNDER DIFFERENT IRRIGATION REGIMES
}

\author{
KinanMadet Kadir ${ }^{1, *}$, Reza Talebi ${ }^{2}$ and Hana Hamidi ${ }^{1}$
}

${ }^{1}$ College of Agriculture, Garmyan University, Kurdistan region, Kifri, Iraq.

${ }^{2}$ Department of Agronomy and Plant Breeding, College of Agriculture and Natural Resources, Islamic Azad University, Sanandaj Branch, Sanandaj, Iran.

Received - January 19, 2017; Revision - February 12, 2017; Accepted - February 28, 2017

Available Online - February 28, 2017

DOI: http://dx.doi.org/10.18006/2017.5(1).054.060

KEYWORDS
Chickpea
Genetic Parameter
Heritability
Drought Stress

\begin{abstract}
In order to evaluate the association between genetic parameters and quantitative drought resistance criteria in chickpea, ten genotypes were evaluated under irrigated and rain-fed field environments. Significant difference was reported among all the measured traits under both environmental conditions. Phenotypic coefficient variation (PCV) ranged from $8.74 \%$ (for Proline) to $19.70 \%$ (for number of seeds per plant) in irrigated environment while it ranged from $9.90 \%$ (for proline) to $19.70 \%$ (for 100 -seed weight) for rainfed condition. The GCV values were the lowest $(8.40 \%)$ for chlorophyll content and highest $(30.71 \%)$ for number of seeds per plant and the lowest $(14.73 \%)$ for plant height and highest $(50.39 \%)$ for 100 -seed weight in irrigated and rain-fed environmental conditions respectively. High heritability values observed in 100-seed weight, number of seeds per plant and seed yield in both environments and also high heritability for physiological traits in rain-fed environment indicating that these traits are controlled mainly by additive genes and that selection of such traits may be effective for improving seed yield in both environments. There was a positive significant correlation between YSI and YI with seed yield, MP and GMP in both environments, suggesting that these parameters are able to discriminate superior group of genotypes under both environments. Results of factor analysis showed that two and three factors explained $80.34 \%$ and $89.66 \%$ of the total variance caused in the characters in irrigated and Rain-fed environment, respectively. High heritability for most of the morphological and physiological traits in both environments indicated that additive gene effects are important in determining these traits and selection based on these traits could be very useful in chickpea breeding program to introduce drought resistance chickpea genotypes for rain-fed climates.
\end{abstract}

* Corresponding author

E-mail: can3an.mad@hotmail.com (KinanMadet Kadir)

Peer review under responsibility of Journal of Experimental Biology and Agricultural Sciences.

Production and Hosting by Horizon Publisher India [HPI] (http://www.horizonpublisherindia.in/).

All rights reserved.
All the article published by Journal of Experimental Biology and Agricultural Sciences is licensed under a Creative Commons Attribution-NonCommercial 4.0 International License Based on a work at www.jebas.org. 


\section{Introduction}

Chickpea (Cicer arietinum L.) is an important legume crop under arid and semi-arid conditions and plays a vital role in the economy of the farming communities resides in these areas. Expanding the improved chickpea cultivars and evolution of these genotypes with narrow genetic bases, making them vulnerable to biotic and biotic stresses and it caused low and unsuitable yield productivity in most chickpea cultivation area (Talebi \& Fayyaz, 2012). Drought is a major abiotic stress which responsible for production losses (Khan et al., 2007). According to Mafakheri et al. (2011), this stress is considered as one of the most important limiting factors for chickpea growth and production. Information on the relative importance of various yield components to seed yield is useful for producers to manage the crop by focusing on key yield components. Different adaptive responses like physiological and biochemical processes, canopy architects, antioxidant and osmotic adjustments have been reported in plants against drought stress (Duan et al., 2007). Any traits in plant that related to seed yield has its own genetic system and depending to heritability and nature of each trait, different environmental effects for yield components has been reported (Mohammadi $\&$ Talebi, 2015). Therefore, separation of heritable and nonheritable components is necessary. This separation should be based on its genotypic and phenotypic coefficient of variation, heritability and genetic gain (Kahrizi \& Mohammadi, 2009; Maniee et al., 2009). Information on the relative importance of various yield components to seed yield is useful for producers to manage the crop by focusing on key yield components. This type of information is also useful for chickpea breeders to establish selection criteria in genetic manipulation (Talebi \& Karami, 2011). The main goal in plant breeding is looking and selection the genotypes with high seed yield and quality. Seed yield is complex trait that directly or indirectly associated with other morphological and physiological traits. Selection based on seed yield and its components should be based on genotypic variance and the proportion of the genetic gain and heritability for each trait (Biçer \& Sakar, 2008; Talebi \& Karami, 2013).

Therefore, the present study was conducted to assess genetic variability and heritability of morphological and physiological traits in different chickpea cultivars constructed to wellwatered and rain-fed conditions in order to select the appropriate genotype(s) that are suited to different environments.

\section{Materials and Methods}

2.1 Plant materials and experiment procedure

Ten chickpea (Cicer arietinum L.) accessions were chosen for the study of seed yield, morphological characters and physiological attributes under irrigated and non-irrigated conditions. Field study was conducted in completely randomized design with three replication under both irrigated and rainfed conditions. Each plot contained four rows (4 meter long) with $0.35 \mathrm{~m}$ distances between rows to rows. Irrigated plot received five supplemented irrigation during flowering and pod-filing stages, while rainfed plots did not receive any supplemented irrigation. For morphological traits characterization, randomly 10 plants from each experimental plot for estimating the number of pods per plant, plant height, number of seeds per plant, weight of one-hundred seed and seed yield per plant. Further, Leaf relative water content was measured by the formula given by Turner, 1981 .

$$
R W C=\frac{\text { leaf fresh weight }- \text { leaf dry weight }}{\text { leaf turgid weight }- \text { leaf dry weight }}
$$

Here leaf turgid weight was measured as the weight of leaf after soaking in water for $12 \mathrm{~h}$ at room temperature and dry weight measured after drying the leaf in $85^{\circ} \mathrm{C}$ for $48 \mathrm{~h}$.

\subsection{Measurement of Physiological Parameters}

At flowering stage (60 days after sowing), fresh leaves sample were collected from the selected plants from each plot and 0.5 $\mathrm{g}$ leaf sample from each plot digested in $3 \%$ (W/V) aqueous sulpho-salycilic acid and the proline content was measured as absorbance of fraction with toluene aspired from liquid phase in $520 \mathrm{~nm}$ by spectrophotometer (Shimadzu UV-VIS 1201). For assessment of leaf chlorophyll content, $0.1 \mathrm{mg}$ of fresh leaf soaked in $80 \%$ acetone and homogenized solution were used for measure total leaf chlorophyll content with the help of spectrophotometer at 663 and $645 \mathrm{~nm}$ wave length (Bates et al., 1973).

\subsection{Data analysis}

All measured data were subjected to variance analysis and mean comparisons using Duncan's test $(P=0.05)$ by SAS software. Pearson correlation between traits and factor analysis were measured using STATISTICA software. Genotypic variance $(\mathrm{GV})$, phenotypic variance $(\mathrm{PV})$, environmental variance $(\mathrm{EV})$ and broad-sense heritability $\left(h i^{2}\right)$ of measured traits were estimated by using formula given by Singh \& Chaudhary (1979).

$$
\begin{gathered}
\mathrm{EV}=\mathrm{MSE} \\
G V=\frac{\mathrm{MSG}-\mathrm{MSE}}{\mathrm{r}} \\
\mathrm{PV}=\frac{E V+G V}{\mathrm{r}}
\end{gathered}
$$

Where, MSE and MSG are the values of mean square for error and genotypes in variance analysis, respectively. Broad-sense heritability was estimated using the following formula: 


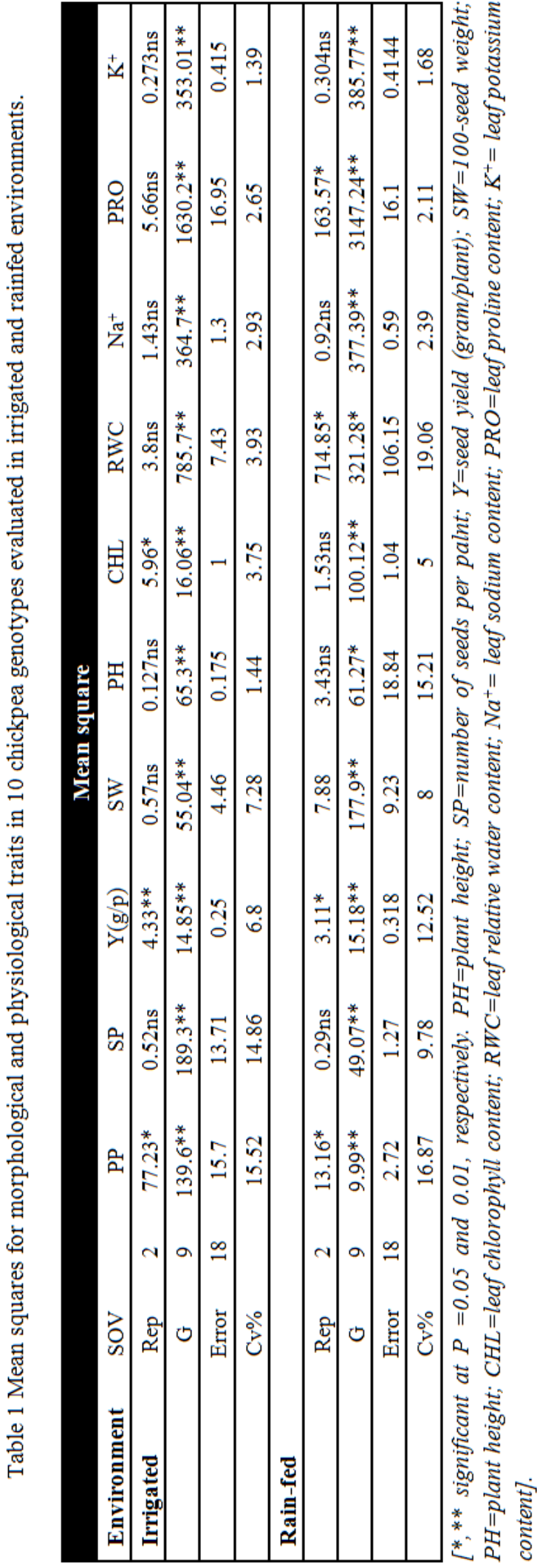

$h i^{2}=\frac{G V}{\mathrm{PV}}$

Genotypic, phenotypic and environmental coefficients of variation were measured using the following formulas:

$\mathrm{GCV}=\frac{\sqrt{G V}}{\overline{\mathrm{U}}} \times 100$

$\mathrm{ECV}=\frac{\sqrt{E V}}{\overline{\mathrm{U}}} \times 100$

$\mathrm{PCV}=\frac{\sqrt{P V}}{\overline{\mathrm{U}}} \times 100$

Where, Uis the mean value of each measured traits.

In addition, quantitative selection criteria including stress susceptibility index (SSI; Fischer \&Maurer, 1978), stress tolerance index (STI; Fernandez, 1992), tolerance (TOL; Rosielle \& Hamblin, 1981), mean productivity (MP; Rosielle \& Hamblin, 1981) and geometric meanproductivity (GMP; Fernandez, 1992) were estimated using grain yield under irrigated (Yp) and drought stress (Ys) conditions. The drought tolerance of chickpea genotypes was evaluated based on these criteria.

\section{Results and Discussion}

3.1 Variance analysis and genetic parameters

Results of variance analysis showed significant differences $(P<0.01)$ for all measured morphological and physiological characters. These differences indicated high diversity for measured traits between genotypes. The experimental coefficient of variation $(\mathrm{CV})$ varied from 1.39 to 15.52 and 1.68 to 16.87 in irrigated and rain-fed environments respectively (Table 1 ).

Plant Breeder success in selecting genotypes possessing higher seed yield and favorable morphological traits depends on the existence and exploitation of genetic variability and high heritability for seed yield and its components. Genotypic, phenotypic and environmental coefficients of variation for all measured traits are presented in Table 2. Lowest and highest value of PCV observed for proline $(8.74 \%)$ and number of seeds per plant $(19.70 \%)$ for proline content ranged from $8.74 \%$ to $19.70 \%$ in irrigated conditions and $9.90 \%$ for proline content to 31.39 for 100 -seed weight rain-fed environment, respectively. The GCV values were the lowest $(8.40 \%)$ for chlorophyll content and highest $(30.71 \%)$ for number of seeds per plant in irrigated conditions while it was the lowest (14.73\%) for plant height and highest $(50.39 \%)$ for 100 -seed weight for rain-fed environmental conditions. Broad sense heritability $\left(\mathrm{hi}^{2}\right)$ were comparatively high for all measured traits in irrigated environment and ranged from 2.17 for 
number of pods per plant to 2.99 for $\mathrm{K}^{+}$content and 1.21 for RWC to 2.99 for $\mathrm{K}^{+}$content in both irrigated and rain-fed environments, respectively (Table 2). These results indicated that measured traits in this study in both irrigated and rain-fed environments can be used for improving seed yield in chickpea. Effective selection in chickpea breeding for traits with higher heritability observed in this study are in accordance with the findings of Zali et al. (2011), Talebi \&
Rokhzadi (2013) and Mohammadi \& Talebi (2015). According to Several characters like number of pods per plant, 100-seed weight, seed yield, RWC and leaf $\mathrm{K}^{+}$content in both environments showed high degree of GCV in chickpea, these findings are in accordance with the findings of Zali et al. (2011) and Mohammadi \& Talebi (2015), this information providing sufficient scope for phenotypic selection.

Table 2 Genetic parameters for different morphological and physiological traitsin chickpea genotypes in irrigated and rain-fed environments.

\begin{tabular}{|ccccccccc|}
\hline & & $\mathbf{E V}$ & $\mathbf{G V}$ & $\mathbf{P V}$ & $\mathbf{G C V}$ & $\mathbf{E C V}$ & $\mathbf{P C V}^{-}$ & $\mathbf{H i}^{\mathbf{2}}$ \\
\hline Irrigated Environment & $\mathrm{PP}$ & 15.7 & 41.3 & 19 & 25.18 & 15.53 & 17.08 & 2.17 \\
\hline & $\mathrm{SP}$ & 13.71 & 58.53 & 24.08 & 30.71 & 14.86 & 19.70 & 2.43 \\
\hline & $\mathrm{Y}$ & 0.25 & 4.86 & 1.7 & 29.55 & 6.70 & 17.48 & 2.86 \\
\hline & $\mathrm{SW}$ & 4.46 & 16.86 & 7.1 & 14.15 & 7.28 & 9.18 & 2.37 \\
\hline & $\mathrm{PH}$ & 0.17 & 21.7 & 7.29 & 16.02 & 1.42 & 9.28 & 2.98 \\
\hline & $\mathrm{CHL}$ & 1 & 5.02 & 2 & 8.40 & 3.75 & 5.30 & 2.51 \\
\hline & $\mathrm{RWC}$ & 7.43 & 259.42 & 88.95 & 23.23 & 3.93 & 13.60 & 2.92 \\
\hline & $\mathrm{Na}^{+}$ & 1.3 & 121.13 & 40.81 & 28.21 & 2.92 & 16.38 & 2.97 \\
\hline $\mathrm{PRO}$ & 16.95 & 537.75 & 184.9 & 14.90 & 2.65 & 8.74 & 2.91 \\
\hline & $\mathrm{K}^{+}$ & 0.41 & 117.53 & 39.31 & 23.40 & 1.38 & 13.54 & 2.99 \\
\hline $\mathrm{PP}$ & 2.72 & 2.42 & 1.71 & 15.96 & 16.92 & 13.41 & 1.42 \\
\hline $\mathrm{SP}$ & 1.27 & 15.93 & 5.73 & 34.59 & 9.77 & 20.74 & 2.78 \\
\hline $\mathrm{Y}$ & 0.318 & 4.95 & 1.75 & 49.44 & 12.53 & 29.40 & 2.83 \\
\hline $\mathrm{SW}$ & 9.23 & 56.22 & 21.81 & 50.39 & 20.42 & 31.39 & 2.58 \\
\hline $\mathrm{PH}$ & 18.84 & 14.14 & 10.99 & 14.73 & 17.00 & 12.99 & 1.29 \\
\hline $\mathrm{CHL}$ & 1.04 & 33.02 & 11.35 & 28.21 & 5.01 & 16.54 & 2.91 \\
\hline $\mathrm{RWC}$ & 106.15 & 71.71 & 59.28 & 15.67 & 19.07 & 14.25 & 1.21 \\
\hline $\mathrm{Na}$ & 0.59 & 125.6 & 42.06 & 34.95 & 2.40 & 20.22 & 2.99 \\
\hline $\mathrm{PRO}$ & 16.1 & 1043.7 & 353.26 & 17.02 & 2.11 & 9.90 & 2.95 \\
\hline $\mathrm{K}{ }^{+}$ & 0.41 & 128.45 & 42.95 & 29.56 & 1.67 & 17.09 & 2.99 \\
\hline
\end{tabular}

[PH=plant height; SP=number of seeds per palnt; Y=seed yield $($ gram/plant $) ; S W=100$-seed weight; PH=plant height; CHL=leaf chlorophyll content; $R W C=$ leaf relative water content; $\mathrm{Na}^{+}=$leaf sodium content; $P R O=$ leaf proline content; $\mathrm{K}^{+}=$leaf potassium content].

Table 3 Drought stress indices in chickpea based of seed yield in irrigated (YP) and rain-fed (YS) environments.

\begin{tabular}{|llllllllll|}
\hline Genotype & YP & YS & MP & GMP & TOL & STI & YSI & YI \\
\hline Hashem & 6.36 & 3.10 & 4.73 & 4.44 & 3.26 & 0.06 & 0.49 & 0.69 \\
\hline ILC482 & 4.22 & 2.92 & 3.57 & 3.51 & 1.30 & 0.02 & 0.69 & 0.65 \\
\hline Flip51-87C & 7.97 & 4.90 & 6.44 & 6.25 & 3.07 & 0.06 & 0.61 & 1.09 \\
\hline Arman & 7.76 & 3.35 & 5.56 & 5.10 & 4.41 & 0.08 & 0.43 & 0.74 \\
\hline Flip2005-3C & 8.52 & 3.58 & 6.05 & 5.52 & 4.94 & 0.09 & 0.42 & 0.79 \\
\hline Flip2005-7C & 8.90 & 6.88 & 7.89 & 7.83 & 2.02 & 0.04 & 0.77 & 1.53 \\
\hline ILC3279 & 4.71 & 1.97 & 3.34 & 3.05 & 2.74 & 0.05 & 0.42 & 0.44 \\
\hline Flip2005-1C & 10.84 & 8.04 & 9.44 & 9.34 & 2.80 & 0.05 & 0.74 & 1.79 \\
\hline ILC263 & 5.42 & 2.57 & 4.00 & 3.73 & 2.85 & 0.05 & 0.47 & 0.57 \\
\hline Flip2005-5C & 9.93 & 7.73 & 8.83 & 8.76 & 2.20 & 0.04 & 0.78 & 1.72 \\
\hline
\end{tabular}


Table 4 Correlation coefficients between Yp, Ys and drought tolerance indices.

\begin{tabular}{|c|c|c|c|c|c|c|c|c|}
\hline & $\mathbf{Y P}$ & YS & MP & GMP & TOL & STI & YSI & YI \\
\hline YP & 1.00 & & & & & & & \\
\hline YS & $0.88^{\text {*** }}$ & 1.00 & & & & & & \\
\hline MP & $0.97^{* *}$ & $0.97^{* *}$ & 1.00 & & & & & \\
\hline GMP & $0.95^{\text {*** }}$ & $0.98^{* * *}$ & $1^{* *}$ & 1.00 & & & & \\
\hline TOL & 0.22 & -0.26 & -0.02 & -0.09 & 1.00 & & & \\
\hline STI & 0.22 & -0.26 & -0.02 & -0.09 & $1^{* * *}$ & 1.00 & & \\
\hline YSI & $0.50^{*}$ & $0.83^{* * *}$ & $0.69^{* * *}$ & $0.73^{* * *}$ & $-0.71^{* * *}$ & $-0.71^{* * k}$ & 1.00 & \\
\hline YI & $0.88^{\text {*** }}$ & $1^{* *}$ & $0.97^{* *}$ & $0.98^{* * *}$ & -0.26 & -0.26 & $0.83^{* *}$ & 1.00 \\
\hline
\end{tabular}

\subsection{Drought tolerance indices}

The genotypes showed significant differences in seed yield and other traits under both environmental conditions. Seed yield, morphological traits and most of physiological parameters under irrigated conditions were decreases in rain-fed environment. Thus, indirect selection for a drought-prone environment based on the results of optimum conditions which will not be efficient (Talebi et al., 2009; Talebi \& Karami 2011). In present study, resistance indices were calculated on the basis of genotypes (Table 3).To determine the most desirable drought tolerance criteria, the correlation coefficient between $\mathrm{Yp}, \mathrm{Ys}$ and other quantitative indices of drought tolerance were calculated (Table 4). A positive correlation was reported between TOL and yield under normal condition (Yp) and a negative correlation was reported between TOL and yield under stress (Ys) (Table 4) suggest that selection based on TOL will results in reduced yield under well-watered conditions. Similar results were reported in several crops like wheat (Talebi et al., 2009), chickpea (Talebi et al., 2011) and barley (Rizza et al., 2004).
The results of study revealed that there were positive and significant correlations among Yp and Ys with MP, GMP and STI were better predictors of Yp and Ys than TOL and SSI. The genotypes Hashem, Arman and Flip 2005-3c with high yield under stress produced a lower yield under non-stress condition and showed the highest STI value (Table 3). STI showed negative correlation with seed yield in both environments (Table 4), suggesting that these parameters could not be efficient parameter for selection superior chickpea genotypes in both environments. Further, significant positive correlation was reported between YSI and YI with seed yield in both environmental conditions and MP and GMP (Table 4), suggesting that these parameters are able to discriminate tolerant group of genotypes under both environments. As STI, GMP and MP were able to identify cultivars producing high yield in both conditions, therefore, these parameters are useful indicators for chickpea breeding under drought stress zones. This finding is in agreement with Talebi et al. (2011) and Talebi \& Karami (2011).

Table 5 Factor analysis for physiological and agro-morphological parameters in chickpea subjected to irrigated and rainfed conditions.

\begin{tabular}{|lccccc|}
\hline & \multicolumn{2}{c}{ Irrigated } & & \multicolumn{2}{c|}{ Rain-fed } \\
\hline & Factor1 & Factor2 & Factor1 & Factor2 & Factor3 \\
\hline Pods per Plant & 0.76 & -0.60 & -0.63 & -0.62 & -0.09 \\
\hline Seeds per Plant & -0.53 & 0.84 & 0.90 & 0.22 & -0.13 \\
\hline Yield (gr/plant) & 0.75 & -0.40 & 0.84 & 0.50 & -0.10 \\
\hline 100-Seed Weight & -0.54 & 0.74 & -0.45 & 0.81 & -0.08 \\
\hline Plant Height & -0.60 & 0.64 & 0.16 & -0.51 & 0.84 \\
\hline Chlorophyll & -0.53 & 0.56 & -0.42 & -0.61 & 0.63 \\
\hline RWC & 0.89 & 0.17 & 0.78 & -0.35 & -0.16 \\
\hline Na+ & 0.90 & -0.01 & 0.95 & 0.10 & -0.02 \\
\hline Proline & 0.80 & 0.00 & 0.97 & -0.10 & -0.06 \\
\hline K+ & 0.94 & -0.03 & 0.92 & -0.15 & 0.12 \\
\hline Eigen Value & 2.179 & 1.18 & 3.11 & 2.42 & 1.25 \\
\hline$\%$ of variance explained & 55.02 & 25.32 & 56.36 & 21.45 & 11.84 \\
\hline Cumulative variance & 55.02 & 80.34 & 56.36 & 77.81 & 89.66 \\
\hline
\end{tabular}


3.3 Factor analysis

Factor analysis combined variables that were correlated into two and three factors in order of the amount of variance in both irrigated and rain-fed environments, respectively (Table 5). In irrigated environment, two factors explained $80.34 \%$ of the total variance caused in the characters (Table 5). The first factor could explain $55.02 \%$ of the total variation. Factor 1 comprised number of pods per plant, seed yield, RWC, Proline, $\mathrm{Na}+$ and $\mathrm{K}+$. These have direct and indirect positive effects on the various growth traits of chickpea. Therefore, this factor can be called the detector yield factors and physiological parameters that related to osmotic adjustment in plant. This result is in agreement with previous studies on chickpea (TalebiandKarami, 2011) and common bean (Sadeghi et al., 2011). Second factor through 100 -seed weight and seeds per plant as most important characters showed $25.32 \%$ of variation (Table 5). Therefore, this factor can also be the detector yield components factors. These results suggested that the selection for high yield chickpea genotypes under optimal condition may be improved by increasing the weight of 100-seed, number of pods per plant, and more partitioning the soluble contents in leaves like $\mathrm{Na}^{+}, \mathrm{K}^{+}$and chlorophyll due to increasing the photosynthesis and consequently increasing the potential yield. In rain-fed environments, three factors explained $89.66 \%$ of the total variance caused in the characters (Table 5).The first factor could explain $56.36 \%$ of the total variation. These factor comprised number of seeds per plant, seed yield, RWC, Proline, $\mathrm{Na}+$ and $\mathrm{K}+$. Like as irrigated environment, these factors can also called the detector yield components factors and osmotic adjustment regulator factor. Second and third factors explained $21.45 \%$ and $11.84 \%$ of variations for 100 seed weight and plant height, respectively (Table 5).These results suggested that the selection for high yield chickpea genotypes under rain-fed condition may be improved by increasing the plant height, 100-seed weight and more partitioning thesoluble contents in leaves to increasing the RWC and consequently increasing the potential yield. These findings are in agreement with Yucel et al., (2006), Ali et al., (2009) and Talebi \& Karami (2011).

Overall these results revealed a wide range of variability for different morphological and physiological traits in both environmental conditions with high heritability for important yield traits hence selection is effective for these traits. Further study on gene action is needed for recommendation of selection of high yield in chickpea in different environmental conditions. Genetic analysis of most of the quantitative traits in chickpea showed additive and non-additive components of genetic variances in relative to inheritance of quantitative traits (Karami \& Talebi, 2013). Broad-sense heritability for seed yield components characters in chickpea has been reported ranged from 11 to $87 \%$ and between quantitative traits in chickpea low heritability for seed yield and plant height due to high effects of these environmental conditions on these traits (Tambal et al., 2000), therefore, early generation selection based on these traits in chickpea could not be useful (Tilahun et al., 2015). According to Ashraf \& Harris (2004) and Zali et al. (2011) selection based on heritability alone is not very useful in breeding program. High heritability for number of seeds per plant, 100-seed weight, seed yield and RWC in both environments indicated that additive gene effects are important in determining these traits. Crop improvement for the straits is assumed to be possible by simple selection, due to high heritability coupled with high genotypic variation and additive gene effects (Noor et al.,2003; Karami \& Talebi, 2013).

\section{Conflict of interest}

Authors would hereby like to declare that there is no conflict of interests that could possibly arise.

\section{References}

Ali MA, Nawab NN, Abbas A, Zulkiffal M, Sajjad M (2009) Evaluation of selection criteria in Cicer arietinum L. using correlation coefficients and path analysis. Australian Journal of Crop Science 3:65-70.

Ashraf M, Harris PJC (2004) Potential biochemical indicators of salinity tolerance in plants. Plant Science 166: 3-16. DOI: http://dx.doi.org/10.1016/j.plantsci.2003.10.024

Bates LS, Waldren RP, Teare ID (1973) Rapid determination of free proline for water-stress studies. Plant Soil 39: 205207.DOI: $10.1007 / \mathrm{BF} 00018060$

Tuba BBT, Sakar D (2008) Heritability and gene effects for yield and yield components in chickpea. Hereditas 145:220224.DOI: $10.1111 / j .1601-5223.2008 .02061 . x$

Duan B, Yang Y, Lu Y, Korpelainen H, Berninger F, Li C (2007)Interactions between drought stress, ABA and genotypes in Picea asperata. Journal of Experimental Botany 58: 30253036.DOI: https://doi.org/10.1093/jxb/erm160

Fernandez GCJ (1992) Effective selection criteria for assessing stress tolerance. In: Kuo CG (Ed.), Proceedings of the International Symposium on Adaptation of Vegetables and Other Food Crops in Temperature and Water Stress, Publication, Tainan, Taiwan.

Fischer RA, Maurer R (1978) Drought resistance in spring wheat cultivars.I., Grain yield response. Australian Journal of Agricultural Research 29: 897-907.

Kahrizi D, Mohammadi R (2009) Study of Androgenesis and Spontaneous Chromosome Doubling in Barley (Hordeum vulgare L.) genotypes using Isolated Microspore Culture. Acta Agronomica Hungarica 57: 155-164.DOI: http://dx.doi.org/10.1556/AAgr.57.2009.2.7

Karami E, Talebi R (2013) Nature of gene action and genetic parameters for yield and its components in chickpea. African Journal of Biotechnology 12:7038-7042.DOI: 10.5897/AJB11.3290 
Khan HR, Link W, Hocking TJ, Stoddard FL (2007) Evaluation of physiological traits for improving drought tolerance in faba bean (Vicia faba L.). Plant and Soil 292:205217.DOI: $10.1007 / \mathrm{s} 11104-007-9217-5$

Mafakheri A, Siosemardeh A, Bahramnejad B, Struik PC, Sohrabi Y (2011) Effect of drought stress and subsequent recovery on protein, carbohydrate contents, catalase and peroxidase activities in three chickpea (Cicerarietinum) cultivars. Australian Journal of Crop Science 5:1255-1260.

Maniee M, Kahrizi D, Mohammadi R (2009) Genetic variability of some morpho-physiological traits in durum wheat (Triticum durum Desf.). Journal of Applied Sciences 9: 13831387. DOI: 10.3923/jas.2009.1383.1387.

Mohammadi KH, Talebi R (2015) Interrelationships and genetic analysis of seed yield and morphological traits in mini core collection of Iranian landrace, breeding lines and improved chickpea (Cicer arietinum L.) cultivars. Genetika 47:383-393. DOI: 10.2298/GENSR1502383M

Noor F, Ashaf M, Ghafoor A (2003) Path analysis and relationship among quantitative traits in chickpea (Cicer arietinum L.). Pakistan Journal of Biological Sciences 6: 551555. DOI: $10.3923 /$ pjbs.2003.551.555

Rizza F, Badeckb FW, Cattivellia L, Lidestric O, Di Fonzoc N, Stancaa AM (2004) Use of a water stress index to identify barley genotypes adapted to rainfed and irrigated conditions. Crop Science 44: 2127-2137. doi:10.2135/cropsci2004.2127

Rosielle AA, Hamblin J (1981) Theoretical aspects of selection for yield in stress and non-stress environment. Crop Science 21: 943

946.doi:10.2135/cropsci1981.0011183X002100060033x

Sadeghi A, Cheghamirza K, Dorri HR (2011) The study of morphoagronomic traits relationship in common bean (Phaseolus vulgaris L.). Biharean Biologist 5:102-108.

Singh RK, Chaudhary BD (1979) Biometrical methods in quantitative genetic analysis. Kalyani Publication, New Delhi. Pp. 303.

Talebi R, Baghebani N, Karami E, Ensafi MH (2011) Defining selection indices for drought tolerance in chickpea under terminal drought stresses. Journal of Applied Biological Sciences 5:33-38.

Talebi R, Fayyaz F (2012) Estimation of heritability and genetic parameters associated with agronomic traits of bread wheat (Triticumaestivum L.) under two constructing water regimes. Journal of Applied Biological Sciences 6: 35-39.

Talebi R, Fayyaz F, Naji AM (2009) Effective selection criteria for assessing drought stress tolerance in durum wheat (Triticum durum Desf.). General and Applied Plant Physiology 35: 64-74.

Talebi R, Karami E (2011) Morphological and physiological traits associated with seed yield in different chickpea (Cicerarietinum L.) genotypes under irrigated and water-deficit environments. South Asian Journal of Experimental Biology 1: 260-267.

Talebi R, Rokhzadi A (2013) Genetic diversity and interrelationships between agronomic traits in landrace chickpea accessions collected from 'Kurdistan' province, north-west of Iran. International Journal of Agronomy and Crop Science 5: 2203-2209.

Tambal HAA, Erskine W, Baalbaki R, Zaiter H (2000) Relationship of flower and pod numbers per inflorescence with seed yield in lentil. Experimental Agriculture 36:369-378.

Tilahun G, Mekbib F, Fikre A (2015) Genetic divergence and character association of kabuli type chickpea (Cicerarietium) genotype under rainfed conditions in Ethiopia. Current Research in Agricultural Research 2(4):123131. DOI: $10.18488 /$ journal.68/2015.2.4/68.4.123.131

Turner NC (1981) Techniques and experimental approaches for the measurement of plant water status. Plant Soil 58: 339366.DOI: $10.1007 / \mathrm{BF} 02180062$

Yücel DO, Anlarsal AE, Yucel C (2006) Genetic variability, correlation, and path analysis of yield and yield components in chickpea(Cicerarietinum L.). Turkish Journal of Agriculture and Forestry 30:183-188.

Zali H, Farshadfar E, Sabaghpour SH (2011) Genetic variability and interrelationships among agronomic traits inchickpea (Cicerarietinum L.) genotypes. Crop Breeding Journal 1: 127-132. 